Article

\title{
High Reserve in $\delta$-Tocopherol of Peganum harmala Seeds Oil and Antifungal Activity of Oil against Ten Plant Pathogenic Fungi
}

\author{
Abdelhamid Hajji ${ }^{1, *,+}$, Fethi Bnejdi ${ }^{1,2}$, Mourad Saadoun $1,+$, Ibtissem Ben Salem ${ }^{2}$, \\ Imededdine Nehdi ${ }^{3}$, Hassen Sbihi ${ }^{3}$, Fahad A. Alharthi ${ }^{3}$, Safia El Bok ${ }^{1}$ \\ and Naima Boughalleb-M'Hamdi ${ }^{2}$ \\ 1 Biodiversity, Biotechnology, and Climate Change Laboratory, Tunis El Manar University, Tunis 2092, Tunisia; \\ Fethibnejdi@yahoo.fr (F.B.); saadoun2003@yahoo.fr (M.S.); safia1elbok@yahoo.fr (S.E.B.) \\ 2 High Institute Agronomic of Chott-Mariem, University of Sousse, Sousse 4042, Tunisia; \\ ibtibesa82@gmail.com (I.B.S.); n.boughalleb@laposte.net (N.B.-M.) \\ 3 Chemistry Department, College of Science, King Saud University, P.O. Box 2455, Riyadh 11451, Saudi Arabia; \\ imed12002@gmail.com (I.N.); hmsbihi@ksu.edu.sa (H.S.); fharthi@ksu.edu.sa (F.A.A.) \\ * Correspondence: Hajji.abdelhamid@hotmail.com \\ + These authors contributed equally to this work.
}

Academic Editors: Thomas Efferth and Francesca Mancianti

Received: 18 July 2020; Accepted: 19 August 2020; Published: 6 October 2020

check for updates

\begin{abstract}
This investigation included the chemical analysis of Peganum harmala (P. harmala) seed oil and its antifungal properties against 10 fungal species. Seed oils of six populations were analyzed using high performance liquid chromatography (HPLC) and gas chromatograph/mass spectrometry (GC-MS). The HPLC analysis indicated that P. harmala seed oil exhibited a very high level of tocopherol contents, with values in the range of $2385.66-2722.68 \mathrm{mg} / 100 \mathrm{~g}$. The most abundant tocopherol isomer was $\delta$-tocopherol (90.39\%), followed by $\gamma$-tocopherol (8.08\%) and $\alpha$-tocopherol (1.14\%). We discovered for the first time the presence of tocotrenols in P. harmala seed oils of the six populations studied. The GC-MS analyses revealed that linoleic acid was the main fatty acid $(65.17 \%)$, followed by oleic acid $(23.12 \%)$, palmitic acid (5.36\%) and stearic acid (3.08\%). We also studied the antifungal activity of seed oil of the Medenine (MD) population on ten fungal pathogens. The antifungal effects differed among pathogens and depended on oil concentrations. Seed oil of the MD population caused a significant decrease in mycelial growth of all fungi tested, with values ranging 31.50-82.11\%, except for Alternaria sp., which showed no inhibition. The antifungal activity against the 10 selected fungi can be explained by the richness in tocols of the extracted oil and make P. harmala a promising crop for biological control. Furthermore, the importance of fatty acids and the wide geographic spread in Tunisia of this species make this crop a potential source of renewable energy.
\end{abstract}

Keywords: Peganum harmala; seed oil; population variability; $\delta$-tocopherol; antifungal activity

\section{Introduction}

Peganum harmala Linn, also known as wild rue, harmel or esphand, is a perennial plant species belonging to the Nitrariaceae family (previously called Zygophyllaceae). The Nitrariaceae is a widespread family including 27 genera and 285 species subdivided into five subfamilies [1]. It consists of herbs, shrubs and trees growing in arid and semi-arid areas, in tropical and subtropical regions [2]. The plant is widely distributed in North Africa, Central Asia and the Middle East and has been introduced into America and Australia [3]. In terms of botany, P. harmala is a highly branched perennial shrub growing up to $1 \mathrm{~m}$ tall with short creeping roots [4]. The plant grows in semi-arid and arid conditions, steppe areas and sandy soils. It possesses narrow leaves, arranged alternately on fleshy, 
bright green and stiff stems. Flowers are solitary, small, pale yellow or white, with five petals, and the flowering period is March-April. The fruit is a capsule (about $6-10 \mathrm{~mm}$ wide) with three chambers. The capsules contain about 50 small black-brown triangular seeds [3].

Peganum harmala plays an important role in local ecosystem restoration as a drought-resistant species and is considered among the most important medicinal plants in North Africa. It is a rich source of $\beta$-carboline alkaloids (e.g., harmine, harmaline, harmalol and harman) and quinazoline alkaloids (e.g., vasicine and vasicinone) [5]. Steroids, anthraquinones, flavonoids, polysaccharides and amino acids are also found in its seeds, flowers, leaves, stems and roots [6].

Various parts of this plant have been used in folk medicine for the treatment of human ailments such as asthma, colic, lumbago, jaundice and menstrual flow [7]. Several pharmacological effects have also been reported, such as insecticidal, anti-malarial and antitumor [8]; antihistaminic, antispasmodic and vasorelaxant [9]; wound-healing, immune-modulating, leukemia-healing and antioxidant activities [10]; and hypoglycemic activities [11]. Furthermore, this plant shows analgesic, anti-inflammatory, antimicrobial and antifungal properties [12]

Recent studies investigated the pharmaceutical application, chemical composition and antimicrobial activity of essential oils extracted from seeds of $P$. harmala [13]. However, there are few reports concerning the chemical composition and microbiological activity of oils extracted from P. harmala seeds [14]. The present paper focuses on the tocols (i.e., tocopherols and tocotrienols) and fatty acid composition of seed oils of $P$. harmala plants, collected from different regions of Tunisia. Based on the wide geographic distribution of P. harmala in Tunisia with semi-arid, arid and Saharan climatic zones, we hypothesized that the geographic origin of the plant affected the tocol and fatty acid contents of the oils extracted from seeds. Various studies showed that tocols and fatty acids have many antifungal activities $[15,16]$. Knowledge of bio-active components would highlight the importance of traditional uses of medicinal plants and enrich the global database of phytochemicals. Plant compounds are usually influenced by geographical distribution. In this study, the principal constituents and antifungal effect of Tunisian P. harmala seed oil were addressed.

\section{Results and Discussion}

\subsection{Seed Oil Content}

The seed oil content and fatty acid composition were determined for six P. harmala populations collected from different regions in Tunisia. Data analysis indicated that seed oil content varied among localities and ranged from $5.75 \%$ to $14.75 \%$ for GF and KO, respectively, with an average of $12.51 \%$ (Table 1). These results were similar to a previous report [17], in which oil content was $10 \%$. This finding supported the use of $P$. harmala as a new source of vegetable oil.

\subsection{Tocol Composition}

Tocols of the six P. harmala oils were presented in Table 1 and supplementary materials. The HPLC analyses showed that Peganum oils were rich on tocols. They contained four tocopherol isomers- $\alpha-$, $\beta-, \gamma$ - and $\delta$-tocopherol (abbreviated $\alpha$-T, $\beta-\mathrm{T}, \gamma-\mathrm{T}$, and $\delta$-T, respectively) -as well as three tocotrienol isomers: $\alpha-, \gamma$ - and $\delta$-tocotrienol ( $\alpha$-T3, $\gamma$-T3 and $\delta$-T3, respectively).

All P. harmala oil samples contained very high amounts of tocols, ranging from 2092.78 (SE) to $3770.66 \mathrm{mg} / 100 \mathrm{~g}(\mathrm{MD})$, with an average of $2722.68 \mathrm{mg} / 100 \mathrm{~g}$. The predominant isomer was clearly $\delta-\mathrm{T}$, representing $90 \%$ of the total tocols and an average content of $2441.78 \mathrm{mg} / 100 \mathrm{~g}$ (Table 2). The $\delta$-T values ranged from 1900.51 (SE) to $3424.41 \mathrm{mg} / 100 \mathrm{~g}$ (MD). The $\gamma$-T was also detected in considerable levels, with contents ranging from 143.18 (SE) to $277.61 \mathrm{mg} / 100 \mathrm{~g}$ (MD), with an average of $205.46 \mathrm{mg} / 100 \mathrm{~g}$ (7.6\%), whereas the $\alpha$-T content varied from $19.27(\mathrm{KO})$ to $51.05 \mathrm{mg} / 100 \mathrm{~g}(\mathrm{GF})$. The $\beta$-T was detected at lower quantities (values ranged $6.17-10.8 \mathrm{mg} / 100 \mathrm{~g}$ ). The $\gamma$-T3 was detected at lower amount, with an average content of $17.3 \mathrm{mg} / 100 \mathrm{~g}$. Previous studies [18-20] reported similar variability in tocol contents, possibly due to the characteristics of regions prospected. In our work, $\delta$-T was the most 
abundant isomer, but in a previous study only low contents of this component were found in most tested vegetable oils (0-6\% of total tocols) [21]. The search for other unconventional oils with a high $\delta$-T content should be pursued.

The tocol contents in P. harmala seed oils determined in this work were very high (average content of $2722.68 \mathrm{mg} / 100 \mathrm{~g}$ ) compared to common vegetable oils such as of eshvarak (1082.35 mg/100 g), olive (42.54 mg/100 g), sunflower (95.02 mg/100 g), soya (179.62 mg/100 g) and corn (152.94 mg/100 g) [21]. Tocols have been widely studied due to their high antioxidant, anti-aging, anticancer and anti-atherosclerosis effects [22,23].

\subsection{Fatty Acid Contents}

The major and minor fatty acid composition of the six P. harmala accessions are listed in Table 2. The major fatty acids identified in P. harmala seed oils were C16:0, C18:0, C18:1 $\omega 7, \mathrm{C} 18: 1 \omega 9$ and C18:2; however, fatty acids, such as vaccenic (C18:1 $\omega 7)$, linolenic (C18:3 $\omega 3)$, arachidic (C20:0), behenic (C22:0) and tetracosanoic (C24:0) acids were detected at lower levels.

\subsubsection{Major Fatty Acids}

Five major fatty acids were identified in the six P. harmala populations from Tunisia. Linoleic acid (C18:2) was the main component detected in P. harmala oil. Previous studies also reported that linoleic acid was the most abundant fatty acid in P. harmala seed oils, with contents ranging from $54.6 \%$ [17] to $59.2 \%$ [24]. The level of C18:2 from the southern and central Tunisia populations were $65.30 \%$ and $64.76 \%$, respectively (Table 2). Oleic acid was the second most abundant fatty acid identified in P. harmala oil, with $23.12 \%$. Values were between $22.28 \%$ (for KO) and $24.34 \%$ (SE), showing a small difference to previous results $[17,24]$. Accessions collected from central Tunisia contained more than $24.0 \% \mathrm{C} 18: 1$, except for MH with 22.75\%, whereas, in those from southern regions, the C18:1 content was less than $24 \%$ and the palmitic acid (C16:0) level was $5.36 \%$. Other studies on P. harmala seed oil reported similar palmitic acid contents of 7\% [17] and 8.4\% [24].

The C18:0 content ranged from a minimum of $2.88 \%$ (GF) to a maximum of $3.31 \%$ (MD), yielding a mean of $3.08 \%$. Similar mean contents of C18:0 were detected in the southern and central Tunisia accessions (Table 2). A narrow range of C18:0 content (3.0-3.4\%), overlapping with the range found in this work, was previously reported $[17,24]$.

\subsubsection{Minor Fatty Acids}

Linolenic acid (C18:3) was the most abundant minor fatty acid component detected in P. harmala seed oils. The minimum and maximum values were $0.21 \%$ and $0.84 \%$, respectively, with a mean of $0.65 \%$ (Table 2). These values differed from previous reports of 3.6\% [17] and $1.4 \%$ [24]. Behenic acid (C22:0) was detected in all samples, with a mean content of $0.37 \%$. However, lignoceric acid (C24:0) was detected only in samples from the southern regions, with values of $0.09 \%(\mathrm{~GB}), 0.23 \%(\mathrm{KO})$ and $0.12 \%(\mathrm{MD})$. The remaining minor fatty acids were C18:1 $\omega 11(0.43 \%)$ and C20:0 $(0.62 \%)$.

The variability in fatty acid contents could be caused by genetic and environmental factors, as mentioned in other studies [25-27]. In fact, our samples were obtained from different Tunisian localities with different geographic specificities. 
Table 1. Means \pm sd of tocol contents as (mg/100 $\mathrm{g}$ and percent) in P. harmala seed oil samples.

\begin{tabular}{|c|c|c|c|c|c|c|c|c|c|c|c|c|c|c|c|}
\hline \multirow{3}{*}{ Population } & \multicolumn{8}{|c|}{ Tocopherols } & \multicolumn{6}{|c|}{ Tocotrienols } & \multirow{2}{*}{ Tocols } \\
\hline & \multicolumn{2}{|c|}{$\alpha-\mathrm{T}$} & \multicolumn{2}{|c|}{$\beta-\mathrm{T}$} & \multicolumn{2}{|c|}{$\gamma$-T } & \multicolumn{2}{|c|}{ 8-T } & \multicolumn{2}{|c|}{$\alpha$-T3 } & \multicolumn{2}{|c|}{$\gamma$-T3 } & \multicolumn{2}{|c|}{ 8-T3 } & \\
\hline & & & & & & & Contents & & & & & & & & Total \\
\hline GF & $51.05 * \pm 1.51^{a}$ & $1.78 \pm 0.05^{a}$ & $9.23 \pm 0.17 \mathrm{a}, \mathrm{b}$ & $0.31 \pm 0.01 \mathrm{a}, \mathrm{b}$ & $213.86 \pm 3.45^{a}$ & $7.45 \pm 0.12 \mathrm{a}, \mathrm{b}, \mathrm{c}$ & $2573.03 \pm 2.70^{\mathrm{a}}$ & $89.63 \pm 0.06^{\mathrm{a}}$ & $3.92 \pm 0.08^{a}$ & $0.14 \pm 0.01^{a}$ & $2.97 \pm 0.01$ & $0.10 \pm 0.00$ & $16.87 \pm 0.14^{a}$ & $0.59 \pm 0.01^{\mathrm{a}}$ & $2870.98 \pm 0.95$ a \\
\hline GB & $29.96 \pm 0.85^{\mathrm{b}}$ & $1.14 \pm 0.04^{\mathrm{b}}$ & $9.91 \pm 0.72 \mathrm{a}, \mathrm{c}$ & $0.37 \pm 0.03^{c, d}$ & $211.57 \pm 2.14^{a}$ & $8.33 \pm 0.50^{\mathrm{a}}$ & $2366.17 \pm 4.12^{b}$ & $89.72 \pm 0.04 \mathrm{a}, \mathrm{b}$ & $2.78 \pm 0.08^{\mathrm{b}}$ & $0.11 \pm 0.01^{b}$ & & & $17.03 \pm 0.58^{a}$ & $0.65 \pm 0.02^{\mathrm{a}}$ & $2637.43 \pm 5.47 b$ \\
\hline Ко & $17.77 \pm 1.56^{\mathrm{c}}$ & $0.86 \pm 0.03^{\mathrm{c}, \mathrm{d}}$ & $6.17 \pm 0.11^{\mathrm{d}}$ & $0.28 \pm 0.01^{\mathrm{b}}$ & $176.77 \pm 1.77^{b}$ & $7.89 \pm 0.08 \mathrm{a}, \mathrm{b}$ & $2022.42 \pm 3.32^{\mathrm{c}}$ & $90.30 \pm 0.08^{c}$ & $1.68 \pm 0.06^{\mathrm{c}}$ & $0.08 \pm 0.01^{\mathrm{c}}$ & - & - & $13.47 \pm 0.38^{b}$ & $0.60 \pm 0.01^{\mathrm{a}}$ & $2239.77 \pm 1.91^{\mathrm{c}}$ \\
\hline MD & $30.03 \pm 0.69^{b}$ & $0.80 \pm 0.02 \mathrm{~d}$ & $10.80 \pm 0.24^{\mathrm{c}}$ & $0.29 \pm 0.01^{\mathrm{ab}}$ & $277.62 \pm 3.54^{\mathrm{c}}$ & $7.36 \pm 0.13 \mathrm{~b}, \mathrm{c}$ & $3424.41 \pm 17.42^{\mathrm{d}}$ & $90.81 \pm 0.10^{\mathrm{d}}$ & $3.82 \pm 0.07^{a}$ & $0.10 \pm 0.00^{\mathrm{b}}$ & - & . & $24.30 \pm 0.30^{c}$ & $0.65 \pm 0.01^{\mathrm{a}}$ & $3770.98 \pm 15.19$ \\
\hline MH & $23.37 \pm 0.62^{\mathrm{d}}$ & $0.89 \pm 0.03 \mathrm{c}, \mathrm{d}$ & $8.81 \pm 0.10^{a, b}$ & $0.34 \pm 0.01 \mathrm{a}, \mathrm{d}$ & $209.76 \pm 2.05$ a & $7.99 \pm 0.06^{a, b}$ & $2363.68 \pm 3.35^{\mathrm{b}}$ & $90.06 \pm 0.03 \mathrm{~b}, \mathrm{c}$ & $2.33 \pm 0.06^{\mathrm{d}}$ & $0.09 \pm 0.00^{b, c}$ & . & . & $16.12 \pm 0.96^{a}$ & $0.62 \pm 0.04^{\mathrm{a}}$ & $2624.57 \pm 4.51^{b}$ \\
\hline SE & $20.36 \pm 0.50^{\mathrm{c}, \mathrm{d}}$ & $0.97 \pm 0.01^{\mathrm{c}}$ & $8.50 \pm 0.24 \mathrm{~b}$ & $0.40 \pm 0.01^{\mathrm{c}}$ & $143.18 \pm 2.63^{\mathrm{d}}$ & $6.84 \pm 0.16^{c}$ & $1900.51 \pm 10.99 \mathrm{e}$ & $90.81 \pm 0.17 \mathrm{~d}$ & $4.27 \pm 0.11^{\mathrm{e}}$ & $0.21 \pm 0.01 \mathrm{~d}$ & $=$ & - & $16.00 \pm 0.54$ a & $0.76 \pm 0.03^{\mathrm{b}}$ & $2092.81 \pm 8.19$ e \\
\hline
\end{tabular}

MH, Mahdia.

Table 2. Means \pm sd of major and minor fatty acids detected in seed oil samples of six P. harmala populations.

\begin{tabular}{|c|c|c|c|c|c|c|c|c|c|c|}
\hline Population & C16:0 & C18:0 & 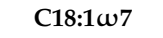 & C18:1w9 & C18:2 & C18:1w11 & $\mathrm{C} 18: 3 \omega 3$ & C20:0 & C22:0 & C24:0 \\
\hline GF & $5.00 \pm 0.03^{\mathrm{a}}$ & $2.88^{*} \pm 0.03^{\mathrm{a}}$ & $1.12 \pm 0.02^{a, b}$ & $23.42 \pm 0.07^{\mathrm{a}}$ & $65.90 \pm 0.08^{\mathrm{a}}$ & $0.37 \pm 0.03^{\mathrm{a}}$ & $0.21 \pm 0.00^{\mathrm{a}}$ & $0.74 \pm 0.04^{\mathrm{a}, \mathrm{b}}$ & $0.32 \pm 0.03^{\mathrm{a}}$ & - \\
\hline GB & $5.54 \pm 0.04^{b}$ & $2.97 \pm 0.00^{\mathrm{a}}$ & $1.19 \pm 0.01 \mathrm{a}, \mathrm{c}$ & $22.86 \pm 0.08^{b, c}$ & $65.65 \pm 0.01^{b}$ & $0.23 \pm 0.00^{b}$ & $0.63 \pm 0.01^{b}$ & $0.65 \pm 0.04^{b, c}$ & $0.20 \pm 0.00^{b}$ & $0.09 \pm 0.03^{\mathrm{a}}$ \\
\hline КО & $5.49 \pm 0.04^{b}$ & $3.12 \pm 0.00^{b}$ & $1.04 \pm 0.01^{b}$ & $22.28 \pm 0.11^{\mathrm{d}}$ & $65.30 \pm 0.07^{c}$ & $0.51 \pm 0.01^{c}$ & $0.84 \pm 0.03^{c}$ & $0.60 \pm 0.00^{c}$ & $0.57 \pm 0.00^{c}$ & $0.23 \pm 0.00^{b}$ \\
\hline MD & $5.46 \pm 0.03^{b}$ & $3.31 \pm 0.03^{c}$ & $1.08 \pm 0.01^{a, b}$ & $23.05 \pm 0.04 \mathrm{~b}$ & $64.36 \pm 0.04 \mathrm{~d}$ & $0.59 \pm 0.00^{\mathrm{d}}$ & $0.81 \pm 0.04^{c}$ & $0.78 \pm 0.00^{a}$ & $0.38 \pm 0.01^{\mathrm{a}, \mathrm{d}}$ & $0.12 \pm 0.00^{\mathrm{a}}$ \\
\hline MH & $5.16 \pm 0.07^{a}$ & $3.25 \pm 0.04^{c}$ & $1.29 \pm 0.06^{c}$ & $22.75 \pm 0.07^{c}$ & $65.09 \pm 0.01^{c}$ & $0.52 \pm 0.03^{c}$ & $0.82 \pm 0.06^{c}$ & $0.69 \pm 0.00 \mathrm{a}, \mathrm{b}, \mathrm{c}$ & $0.40 \pm 0.01^{\mathrm{d}}$ & - \\
\hline
\end{tabular}

* Means within the same column with different superscript letters (a, b, c, d, e) are significantly different ( $p<0.05)$. GF, Gafsa; GB, Gabes; KO, Koutine; MD, Medenine; SE, Sousse; MH, Mahdia. 


\subsection{Antifungal Activity}

The in vitro antifungal activity of $P$. harmala seed oils against selected fungi is shown in Table 3. The inhibition values of mycelia growth varied from $31.53 \%(6)$ to $82.11 \%$ (3) at the $1 / 2$ concentration. The ANOVA of antifungal activity data showed significant differences between the fungal isolates and the seed oil concentrations $(p<0.05)$. In addition, we noted a significant fungal isolate $\times$ oil concentration interaction $(p<0.05)$. The minima and the maxima concentrations of mycelia growth inhibition varied depending on the fungi tested (Table 3). The P. harmala seed oils exhibited excellent activity against (3) with mycelia growth inhibition ranging within 56-82\%, followed by (8)-(10) with inhibitions of $15-55.7 \%, 20-54 \%$ and $5-58 \%$, respectively. The seed oil showed moderate inhibition against (6), with range of 5.19-42\%. The evaluated seed oils manifested promising antifungal activities against the tested fungi except for (5), which showed no inhibitory effect. Orange essential oil was found to have potential for controlling A. dauci and A. alternata [28]. The preponderance of linoleic and oleic acids determined by GC-MS analysis of seed oil of the MD population reinforced the antifungal activity of $P$. harmala shown in our study. This is consistent with other studies on the importance of linolenic, linoleic and oleic acids as essential components of seed oil of many plants such as Pongamia pinnata, which exhibited a strong antifungal and antibacterial properties [16,29]. Other studies revealed the effectiveness of Moringa peregrine against several microorganisms [30].

Table 3. Antifungal activity (\%) of different seeds oil concentrations of $P$. harmala on 10 fungal isolates.

\begin{tabular}{|c|c|c|c|c|c|c|c|c|c|c|}
\hline \multirow{2}{*}{ Fungal Isolates } & \multicolumn{10}{|c|}{ Seeds Oil Concentrations } \\
\hline & $1 / 2$ & $1 / 4$ & $1 / 8$ & $1 / 16$ & $1 / 32$ & $1 / 64$ & $1 / 128$ & $1 / 256$ & $1 / 512$ & DMSO \\
\hline 1 & 33.46 & 30.76 & 28.84 & 21.61 & 21.15 & 23.84 & 16.15 & 15.38 & - & - \\
\hline 2 & 36.53 & 37.30 & 37.30 & 31.73 & 29.42 & 15.38 & 9.61 & 5.76 & - & - \\
\hline 3 & 82.11 & 76.92 & 56.34 & - & - & - & - & - & - & - \\
\hline 4 & 42.11 & 41.73 & 30.76 & 30.19 & 5.61 & 5.19 & - & - & - & - \\
\hline 5 & - & - & - & - & - & - & - & - & - & - \\
\hline 6 & 31.53 & 31.34 & 14.80 & 15.38 & - & - & - & - & - & - \\
\hline 7 & 53.84 & 51.92 & 35.38 & 37.80 & 38.46 & 28.84 & 20.57 & 20.00 & - & - \\
\hline 8 & 62.88 & 47.50 & 35.19 & 29.42 & 35.19 & 41.15 & 37.30 & 36.53 & - & - \\
\hline 9 & 55.70 & 29.61 & 26.34 & 25.76 & 11.53 & 20.57 & 15.96 & 14.86 & - & - \\
\hline 10 & 57.69 & 53.84 & 39.23 & 26.15 & 21.15 & 22.88 & 5.76 & 5.19 & - & \\
\hline
\end{tabular}

Rhizoctonia solani (1); Macrophomina phaseolina (2); Pythium sp.1 (3); Pythium sp. 2 (4); Alternaria sp. (5); Colletotrichum sp. (6); Monosporascus cannonballus (7); Fusarium solani f.sp. cucurbitae (8); Fusarium oxysporum f.sp. melonis (9); and Fusarium oxysporum f.sp. niveum (10).

Other works have highlighted the activity of essential oils on growth of many bacteria species. Essential oils of Melaleuca showed strong inhibitory effects against E. coli, P. aeruginosa and S. enteric, with inhibition of about $89 \%$ [31]. Biocontrol strategy is still by far the sustainable alternative control against fungal diseases [32]. Seed oil of P. harmala exhibited good antioxidant and anti-inflammatory activities [14] and will be considered in further investigations to identify the compounds responsible for the biological activities of the oil. Recently the biological activities, individually, of isomers of vitamin $\mathrm{E}$ $(\alpha$ - and $\gamma$-T) were reported [33,34]. [35] mentioned that soybean and palm oils were major commercial sources of tocopherols $(20 \% \delta$-T and $65 \% \gamma-\mathrm{T})$ and tocotrienols, respectively. To our knowledge, the biological activity of $\delta$-T, separately, has not been well studied and should be considered in further work, especially because we found a high $\delta$-T content in our study.

Determination of Minimum Inhibitory Concentrations (MICs) and Percentage of Mycelial Growth Inhibition (MGI)

The MICs ranged within 3.9-125.0 $\mu \mathrm{L} / \mathrm{mL}$ (dilutions $1 / 8$ to $1 / 256$ ). The antifungal activity indicated that seed oil inhibited the growth of all tested fungi at all dilutions, except for (5), which was resistant against all concentrations (Table 4). Orange essential oil has shown potential to control A. dauci and A. alternata [27]. Our results show that the bioactivity of the seed oil depended on the fungi isolates. 
The MIC values were $3.9 \mu \mathrm{L} / \mathrm{mL}$ for six fungal isolates and 15.6, 62.5 and $125.0 \mu \mathrm{L} / \mathrm{mL}$ for (6), (4) and (3), respectively.

Table 4. Percentages of mycelial growth inhibition (MGI) and the minimum inhibitory concentration (CMI) of $P$. harmala seeds oil on 10 fungal pathogen species.

\begin{tabular}{ccc}
\hline Pathogens & MGI (\%) & CMI $(\mu \mathrm{L} / \mathbf{m L})$ \\
\hline $\mathbf{1}$ & 33.4 & 3.9 \\
$\mathbf{2}$ & 31.75 & 3.9 \\
$\mathbf{3}$ & 82.11 & 125 \\
$\mathbf{4}$ & 41.73 & 15.62 \\
$\mathbf{5}$ & 0.00 & - \\
$\mathbf{6}$ & 31.53 & 62.5 \\
$\mathbf{7}$ & 51.92 & 3.9 \\
$\mathbf{8}$ & 62.88 & 3.9 \\
$\mathbf{9}$ & 55.76 & 3.9 \\
$\mathbf{1 0}$ & 57.69 & 3.9
\end{tabular}

Rhizoctonia solani (1); Macrophomina phaseolina (2); Pythium sp.1 (3); Pythium sp. 2 (4); Alternaria sp. (5); Colletotrichum sp. (6); Monosporascus cannonballus (7); Fusarium solani f.sp. cucurbitae (8); Fusarium oxysporum f.sp. melonis (9); and Fusarium oxysporum f.sp. niveum (10).

\section{Materials and Methods}

\subsection{Sources of P. harmala Seeds}

P. harmala fruits were collected from different central and southern Tunisian sites (Table 5). The geographic coordinates corresponding to the location of each fruit sample are also given in Table 5.

Table 5. Geographical coordinates corresponding to the location of collected P. harmala fruits samples and oil seed yields.

\begin{tabular}{ccccccc}
\hline Code & Region Name & Location & Latitude & Longitude & Altitude (m) & Oil Content (\%) \\
\hline GF & Gafsa & South Tunisia & $3425 \mathrm{~N}$ & $0847 \mathrm{E}$ & 298 & 5.72 \\
GB & Gabes & South Tunisia & $3352 \mathrm{~N}$ & $1005 \mathrm{E}$ & 9 & 13.54 \\
KO & Koutine & South Tunisia & $3345 \mathrm{~N}$ & $1034 \mathrm{E}$ & 81 & 14.75 \\
MD & Mednine & South Tunisia & $3321 \mathrm{~N}$ & $1030 \mathrm{E}$ & 90 & 7 \\
MH & Mahdia & Central Tunisia & $3530 \mathrm{~N}$ & $1103 \mathrm{E}$ & 7.83 \\
SE & Sousse & Central Tunisia & $3549 \mathrm{~N}$ & $1038 \mathrm{E}$ & 24 & 13.98 \\
\hline
\end{tabular}

\subsection{Seed Oil Extraction}

The mature seeds collected from fruits were dried and then milled in a K/IKA-WERKE M20 grinder. The seed oil was extracted as follows: $80 \mathrm{~g}$ of ground seeds were placed in a cellulose paper cone mixed with $250 \mathrm{~mL}$ of $n$-hexane using a Soxhlet extraction apparatus for $8 \mathrm{~h}$. The hexane was then removed by rotary evaporation (model R-210, Büchi, Flawil, Switzerland) at $80{ }^{\circ} \mathrm{C}$ and finally stored at $-20^{\circ} \mathrm{C}$ for further analysis. The oil content was expressed as the lipid content percentage on seed powder. All chemicals and reagents used were of analytical grade and were obtained from Merck (Darmstadt, Germany), Sigma-Aldrich (Steinheim, Germany), Acros Organics (Fair Lawn, NJ, USA) and Fisher Scientific Co. (Leicestershire, UK).

\subsection{Determination of Tocol Content}

The tocols present in P. harmala seed oils were analyzed by high performance liquid chromatography (HPLC) according to the ISO 9936 standard. The HPLC system was equipped with a Shimadzu LC-20AT pump (Shimadzu, Kyoto, Japan), a Shimadzu RF 20A fluorescence detector (set at excitation and emission wavelengths of 295 and $330 \mathrm{~nm}$, respectively) and a Rheodyne $7725 \mathrm{i}$ manual injector (Rohnert Park, CA, USA). The tocols were separated on a normal phase column 
(Hypersil silica, $15 \mathrm{~cm}$ length $\times 3 \mathrm{~mm}$ internal diameter, $3 \mu \mathrm{m}$ particle size, Thermo Scientific) at ambient temperature and with mobile phase flow level of $0.5 \mathrm{~mL} / \mathrm{min}$. The mobile phase was a 99.5:0.5 $(v / v) n$-hexane/isopropanol mixture. The data were analyzed using the Shimadzu LC solution software Version 2.53. Of seed oil, $0.5 \mathrm{~g}$ was diluted with $50 \mathrm{~mL}$ of hexane, and $20 \mu \mathrm{L}$ of this was injected into the column. A mixture of standard tocol isomers (Sigma Chemical Co., St. Louis, MO, USA.) was dissolved in hexane at $2 \mu \mathrm{g} / \mathrm{mL}$ each and used for identification and quantification of the HPLC peaks. The amount of tocols in extracts was calculated as $\mathrm{mg}$ tocols/100 $\mathrm{g}$ oil.

\subsection{Determination of Fatty Acid Composition}

The fatty acid methyl esters (FAME) composition was determined by converting the oil to fatty acidmethyl esters by addition of $1 \mathrm{~mL}$ of n-hexane to $40 \mathrm{mg}$ of oil followed by $200 \mu \mathrm{L}$ of sodium methoxide $(2 \mathrm{M})$. The mixture is heated in the bath at $50{ }^{\circ} \mathrm{C}$ for a few seconds followed by adding $200 \mu \mathrm{L} \mathrm{HCl}(2 \mathrm{~N})$. The top layer $(1 \mu \mathrm{L})$ was injected onto a GC (Agilent $6890 \mathrm{~N}$, Santa Clara, CA, USA) equipped with a flame ionization detector (FID) and a polarcapillary column (HP-Innowax polyethylene glycol, $0.25 \mathrm{~mm}$ internal diameter, $30 \mathrm{~min}$ length and $0.25 \mu \mathrm{m}$ film in thickness) to obtain individual peaks of fatty acid methyl esters. The detector temperature was $275^{\circ} \mathrm{C}$ and the column temperature was $150{ }^{\circ} \mathrm{C}$ held for min and increased at the rate of $15^{\circ} \mathrm{C} / \mathrm{min}$ to $200{ }^{\circ} \mathrm{C}$ and the rate of $2{ }^{\circ} \mathrm{C} / \mathrm{min}$ to $250^{\circ} \mathrm{C}$ and held for $4 \mathrm{~min}$. The run time was $45 \mathrm{~min}$. The fatty acid methyl esters peaks were identified comparing their retention times with individual standard FAME (approximately 99\% pure purchased from Supelco, Bellefonte, PA, USA) and analyzed with the Agilent Technologies Chemstation A09.01 Software. The relative percentage of the fatty acid was calculated on the basis of the peak area of a fatty acid species to the total peak area of all the fatty acids in the oil sample. Fatty acid methyl esters peak identification was confirmed by GC-MS (NIST 2002 database) operating under similar conditions as used for the GC-FID.

\subsection{Antifungal Activity of Seed Oil}

\subsubsection{Fungal Isolates}

Ten fungal isolates (Rhizoctonia solani (1); Macrophomina phaseolina (2); Pythium sp.1 (3); Pythium sp. 2 (4); Alternaria sp. (5); Colletotrichum sp. (6); Monosporascus cannonballus (7); Fusarium solani f.sp. cucurbitae (8); Fusarium oxysporum f.sp. melonis (9); and Fusarium oxysporum f.sp. niveum (10)) were identified and conserved in the Laboratory of Phytopathology of the High Institute of Agronomy of Chott-Mariem in Tunisia. Before testing antifungal activity of seed oil, fungal isolates (one for each species) were grown on Potato Dextrose Agar media for 7-10 days.

\subsubsection{Effect of Seed Oil on Mycelia Growth}

The P. harmala seed oil of the MD population was incorporated into melted agar at a desired final concentration and mixed well. Stock solution of $100 \mathrm{mg} / \mathrm{mL}$ was prepared by dissolving $5 \mathrm{~g}$ of oil with $0.5 \mathrm{~mL}$ of dimethyl sulfoxide (DMSO) and diluted up to $50 \mathrm{~mL}$ with distilled water. The serial dilution method $\left(1 / 2^{\mathrm{n}}\right)$ from the prepared stock solution was used to prepare nine different concentrations: D1, $500 \mu \mathrm{L}$ oil/500 $\mu \mathrm{L}$ DMSO; D2, $250 \mu \mathrm{L}$ oil/750 $\mu \mathrm{L}$ DMSO; D3, $125 \mu \mathrm{L}$ oil//875 $\mu \mathrm{L}$ DMSO; D4, $62.5 \mu \mathrm{L}$ oil/937.5 $\mu \mathrm{L}$ DMSO; D5, 31.25 $\mu \mathrm{L}$ oil//968.75 $\mu \mathrm{L}$ DMSO; D6, $15.62 \mu \mathrm{L}$ oil//984.38 $\mu \mathrm{L}$ DMSO; D7, $7.81 \mu \mathrm{L}$ oil/992.19 $\mu \mathrm{L}$ DMSO; D8, 3.9 $\mu \mathrm{L}$ oil/996.1 $\mu \mathrm{L}$ DMSO; and D9, $1.95 \mu \mathrm{L}$ oil/998.05 $\mu \mathrm{L}$ DMSO. The negative control was DMSO (1\%). Mycelia disks (0.7-mm diameter), from five-day-old cultures, of the isolates used were deposited in the center of the plates. Mycelium growth was measured after 48, 72 and $96 \mathrm{~h}$ of incubation in darkness at $25^{\circ} \mathrm{C}$. Three replicates were used for each concentration. Each measure was compared with the control cultures under the same conditions. The percent inhibition of growth diameter (IP) was calculated accordingly to the following formula:

$$
\mathrm{IP}=(\mathrm{C}-\mathrm{T}) / \mathrm{C} \times 100
$$


where $\mathrm{C}$ and $\mathrm{T}$ represent the mean diameter of three replicates of mycelia growth in control and treated slides, respectively.

\subsection{Statistical Analysis}

A one-way analysis of variance (ANOVA) procedure was applied, using Minitab Statistical Software Release 14 (Minitab Inc., State College, PA, USA). Significance differences between reported means were established at $p<0.05$ according to Tukey's test.

\section{Conclusions}

All seed oils of $P$. harmala populations contained very high levels of tocols $(2722.68 \mathrm{mg} / 100 \mathrm{~g})$, with $\delta$-T the most abundant isomer $(2441.78 \mathrm{mg} / 100 \mathrm{~g})$ followed by $\gamma$-T $(205.46 \mathrm{mg} / 100 \mathrm{~g})$. We noted also the presence of tocotrienols for the first time in $P$. harmala. The preponderance of the two components $(\delta-$ and $\gamma-T)$ explained the pertinent antifungal activity against the selected fungi and suggests that $P$. harmala has promise as an alternative approach for biological control of other microorganisms. In addition, the high levels in fatty acids in the $P$. harmala seeds, compared with other plants cited in the literature, revealed the importance of this plant as a new potential source of biofuel and for further medicinal applications. This idea is supported by the wide geographic spread of $P$. harmala in Tunisia and the adaptability of this species to various climactic conditions.

Supplementary Materials: The following are available online.

Author Contributions: Writing-original draft preparation, A.H.; Methodology, F.B.; Writing-review and editing, M.S.; Data curation I.B.S., I.N., H.S., and F.A.A.; Validation, N.B.-M. and S.E.B. All authors have read and agreed to the published version of the manuscript.

Funding: This work was supported in part by Researcher Supporting Project number (RSP-2020/160), King Saud University, Riyadh, Saudi Arabia.

Acknowledgments: We thank Colin Hanbary (Department of Agriculture and Food, Western of Australia) for improving the English of the manuscript.

Conflicts of Interest: The authors declare no conflict of interest.

\section{References}

1. Sheahan, M.C.; Chase, M.W. Phylogenetic relationships within Zygophyllaceae based on DNA sequences of three plastid regions, with special emphasis on Zygophylloideae. Syst. Bot. 2000, 25, 371-384. [CrossRef]

2. Abdel Khalik, K.N. A numerical taxonomic study of the family Zygophyllaceae from Egypt. Acta Bot. Bras. 2012, 26, 165-180. [CrossRef]

3. Mahmoudian, M.; Jalilpour, H.; Salehian, P. Toxicity of Peganum harmala: Review and a case report. Iran. J. Pharmacol. Ther. 2002, 1, 4 .

4. Lamchouri, F.; Settaf, A.; Cherrah, Y.; Zemzami, M.; Lyoussi, B.; Zaid, A.; Hassar, M. Antitumor principles from Peganum harmala seeds. Therapie 1999, 54, 753-758. [PubMed]

5. Kartal, M.; Altun, M.L.; Kurucu, S. HPLC method for the analysis of harmol, harmalol, harmine and harmaline in the seeds of Peganum harmala L. J. Pharm. Biomed. Anal. 2003, 31, 263-269. [CrossRef]

6. Shao, H.; Huang, X.; Zhang, Y.; Zhang, C. Main Alkaloids of Peganum harmala L. and their different effects on Dicot and Monocot Crops. Molecules 2013, 18, 2623-2634. [CrossRef]

7. Bukhari, B.; Choi, J.H.; Jeon, C.W.; Park, H.W.; Kim, W.H.; Khan, M.A.; Leet, S.H. Phytochemical studies of the alkaloids from Peganum harmala. Appl. Chem. 2008, 12, 101-104.

8. Goel, N.; Singh, N.; Saini, R. Efficient in vitro multiplication of Syrian Rue (Peganum harmala L.) using 6-benzylaminopurine pre-conditioned seedling explants. Nat. Sci. 2009, 7, 129-134.

9. Asghari, G.; Lockwood, G.B. Stereospecific biotransformation of phenylethyl propionate by cell cultures of Peganum harmala L. Iran. Biomed. J. 2002, 6, 43-46.

10. Zaker, F.; Oody, A.; Arjmand, A. A study on the anti-tumoral and differentiation effects of Peganum harmala derivatives in combination with ATRA on leukaemic cells. Arch. Pharm. Res. 2007, 30, 844-849. [CrossRef] 
11. Singh, A.B.; Chaturvedi, J.P.; Narender, T.; Srivastava, A.K. Preliminary studied on the hypoglycemic effect of Peganum harmala seeds ethanol extract on normal and streptozocine induced diabetic rats. Indian J. Clin. Biochem. 2008, 23, 391-393. [CrossRef] [PubMed]

12. Diba, I.K.; Shoar, G.M.; Shabatkhori, M.; Khorshivand, Z. Anti-fungal activity of alcoholic extract of Peganum harmala seeds. J. Med. Plants Res. 2011, 5, 5550-5554.

13. Apostolico, I.; Aliberti, L.; Lucia Caputo, L.; Feo, V.; Fratianni, F.; Nazzaro, F.; Souzab, L.; and Khadhr, M. Chemical composition, antibacterial and phytotoxic activities of Peganum harmala seed essential oils from five different localities in Northern Africa. Molecules 2016, 21, 1235. [CrossRef]

14. Khadhr, M.; Bousta, D.; Hanane, E.H.; El Mansouri, L.; Lachkar, M.; Jamoussi, B.; Boukhchina, S. HPLC and GC-MS analysis of Tunisian Seeds oil and evaluation of some biological activities. Am. J. Ther. 2016, 24, e706-e712. [CrossRef] [PubMed]

15. McGaw, L.J.; Ja“ger, A.K.; van Staden, J. Antibacterial effects of fatty acids and related compounds from plants. South Afr. J. Bot. 2002, 68, 417-423. [CrossRef]

16. Kesari, V.; Das, A.; Rangan, L. Physico-chemical characterization and antimicrobial activity from seed oil of Pongamia pinnata, a potential biofuel crop. Biomass Bioenergy 2010, 34, 108-115. [CrossRef]

17. Hassana, L.M.I.; El Hadek, M. Analyse de la composition de l'huile de Peganum harmala L. (Zygophyllaceae). Acta Bot. Gall. 1999, 146, 353-359. [CrossRef]

18. Lavedrine, F.; Ravel, A.; Poupard, A.; Alary, J. Effect of geographic origin, variety and storage on tocopherol concentrations in walnuts by HPLC. Food Chem. 1997, 58, 135-140. [CrossRef]

19. Matthäus, B.; Ozcan, M. Glucosinolates and fatty acid, sterol, and tocopherol composition of seed oils from Capparis spinosa var. spinosa and Capparis ovata Desf. var. canescens (Coss.) Heywood. J. Agric. Food Chem. 2005, 53, 7136-7141.

20. Tlili, N.; Nasri, N.; Saadaoui, E.; Khaldi, A.; Triki, S. Sterol composition of caper (Capparis spinosa) seeds. Afr. J. Biotechnol. 2010, 9, 3328-3333.

21. Nehdi, I.A.; Sbihi, H.; Tan, C.P.; Al Resayes, S.I. Leucaena leucocephala (Lam.) de wit seed oil: Characterization and uses. Ind. Crop. Prod. 2014, 52, 582-587. [CrossRef]

22. Brigelius-Flohé, R.; Traber, M.G. Vitamin E: Function and metabolism. FASEB J. 1999, 13, 1145-1155. [CrossRef] [PubMed]

23. Saldeen, K.; Saldeen, T. Importance of tocopherols beyond alpha-tocopherol: Evidence from animal and human studies. Nutr. Res. 2005, 25, 877-889. [CrossRef]

24. Asilbekova, D.T. Lipids from the arial part of Peganum harmala. Chem. Nat. Compd. 2006, 42, $223-225$. [CrossRef]

25. Tlili, N.; Sakouhi, F.; Elfalleh, W.; Triki, S.; Khaldi, A. Fatty Acids, total phenols and protein of Caper, Acacia, Cactus and Carob seeds. Asiat. J. Biotechnol. Resour. 2011, 2, 384-390.

26. Lajnef, H.B.; Mejri, H.; Feriani, A.; Khemiri, S.; Saadaoui, E.; Nasri, N.; Tlili, N. Prosopis farcta seeds: Potential source of protein and unsaturated fatty acids. J. Am. Oil Chem. Soc. 2015, 92, 1043-1050. [CrossRef]

27. Atanasove, A.G.; Madania, K.; Boulekbache-Makhloufa, L.; Lizardi, G. Comparison of chemical composition and biological activities of Algerian seed oils of Pistacia lentiscus L., Opuntia ficus indica (L.) mill. and Argania spinosa L. Skeels. Ind. Crop. Prod. 2020, 151, 112456.

28. Batista, C.; Lopes, L.; Rentschler, A.; Tavares, I.; Bueno Ana, B.; Boaventura, C. Plant extracts and essential oils on the control of Alternaria alternata, Alternaria dauci and on the germination and emergence of carrot seeds (Daucus carota L.). Ciência Rural 2016, 46, 764-770.

29. McCusker, M.M.; Grant-Kels, J.M. Healing fats of the skin: The structural and immunologic roles of the $x-6$ and x-3 fatty acids. Clin. Dermatol. 2010, 28, 440-451. [CrossRef]

30. Stavros, L.; Gortzi, O.; Athanasiadis, V.; Tsaknis, J.; Chinou, I. Determination of antimicrobial activity and resistance to oxidation of Moringa peregrina seed oil. Molecules 2012, 17, 2330-2334.

31. Siddique, S.; Parveen, Z.; Firdaus-e-Bareen; Mazhar, S. Chemical composition, antibacterial and antioxidant activities of essential oils from leaves of three Melaleuca species of Pakistani flora. Arab. J. Chem. 2020, 13, 67-74. [CrossRef]

32. Barratt, B.I.P.; Moran, V.C.; Bigler, F.; van Lenteren, J.C. The status of biological control and recommendations for improving uptake for the future. BioControl 2018, 63, 155-167. [CrossRef] 
33. Marmesat, S.; Morales, A.; Ruiz-Méndez, M.V.; Gloria Márquez-Ruiz, G.; Velasco, J. Inhibition of hydroperoxy, keto and hydroxyl FAME by alpha -and delta-tocopherol at Rancimat conditions. J. Am. Oil Chem. Soc. 2016, 93, 93-103. [CrossRef]

34. Ghimire, B.K.; Seong, E.S.; Yu, C.Y.; Kim, S.H.; Chung, I.M. Evaluation of phenolic compounds and antimicrobial activities in transgenic Codonopsis lanceolata plants via overexpression of the $\gamma$-tocopherol methyltransferase ( $\gamma$-tmt) gene. S. Afr. J. Bot. 2017, 109, 25-33. [CrossRef]

35. Hunter, S.; Cahoon, E. Enhancing vitamin E in oilseeds: Unraveling Tocopherol and Tocotrienol biosynthesis. Lipids 2007, 42, 97-108. [CrossRef]

Sample Availability: Samples of the compounds are not available from the authors.

(C) 2020 by the authors. Licensee MDPI, Basel, Switzerland. This article is an open access article distributed under the terms and conditions of the Creative Commons Attribution (CC BY) license (http://creativecommons.org/licenses/by/4.0/). 